Original Article

\title{
Lowland amphibians - recalculation of data on effects of diluted thyroxine
}

\author{
Peter Kiefer, Gerhard Lingg and Peter Christian Endler
}

\author{
Interuniversity College for Health and Development Graz / Castle of Seggau
}

\begin{abstract}
Our previous paper described methodological problems and a generally acceptable pooling method for metamorphosis experiments and application of that method to the results of multicentre experiments performed over the course of two decades (1990 - 2010) on highland amphibians (Rana temporaria) treated with a homeopathically prepared high dilution of thyroxine ("30x"). Differences between treatment groups thus calculated were in line with those obtained with other pooling methods: Thyroxine 30x does slow down metamorphosis in highland amphibians. This follow up paper provides a broader background on metamorphosis physiology and describes application of the pooling method to experiments with Rana temporaria from lowland biotopes both with a moderate dilution of thyroxine ("8x") and with 30x. Analogously prepared water was used for control (water 8x or 30x). Development was, again as above, monitored by documenting the number of animals that had entered the 4-legged stage. Experiments were carried out between 1990 and 2000 by different researchers independently and in blind. As it is well known, metamorphosis can be speeded up by thyroxine $10-8 \mathrm{~mol} / \mathrm{l}$; interestingly, thyroxine $8 \mathrm{x}$ may produce a reverse, i.e. inhibiting effect $(p<0.01)$. In contrast to the inhibiting effect of thyroxine $30 \mathrm{x}$ on highland larvae (see above), 2-legged lowland larvae did not react to thyroxine 30x ( $\mathrm{p}>$ 0.05). However, an inhibiting effect on lowland larvae was found when animals were treated from the spawn stage on $(\mathrm{p}<0.01)$.
\end{abstract}

Keywords: homeopathy, dilution, bio-assay, thyroxine, amphibians

\section{Introduction}

\section{Research topics in homeopathy}

A number of studies regarding fundamental research on homeopathy are available in the literature [1-13]. For example, intoxication studies are an interesting tool for research in this field. In such studies, an organism is first intoxicated with an agent in a sufficiently high dose and then an attempt at detoxification or "cure" is made by application of the same agent prepared according to homeopathic procedures, i.e. in a process of stepwise dilution and agitation (“potentization”) [5,10,13].

This paper review and discusses research results obtained between 1990 and 2000 by the author and his workgroup with a non-invasive experimental model in amphibians, as well as by independent colleagues that took part in multi-researcher studies employing the same model. 
Sensitivity of amphibian metamorphosis to substances prepared according homeopathic procedures was first described by Koenig in the 1930s [14]. In some of the experiments reported here, animals were hyperstimulated with thyroxine before an attempt at "cure" was made by the application of thyroxine in potentiated form.

\section{Physiology of amphibian metamorphosis}

Thyroxine (tetraiodothyronine, $\mathrm{T}_{4}$, a thyroid hormone) plays an important role in the regulation of metamorphosis speed in amphibians. When thyroxine is added to an aquarium water to attain final concentration 1.1 or $2.2 \times 10^{-8} \mathrm{~mol} / \mathrm{l}$, it induces or accelerates the metamorphosis of amphibians respectively $[15,16]$. Thyroxine concentration $1.1 \times 10^{-7} \mathrm{~mol} / \mathrm{l}$ or lower causes an acceleration of development to such extent that deformities appear in the animals [17]. In previous experiments, L-thyroxine sodium pentahydrate (Sigma) at concentration $1.1 \times 10^{-8} \mathrm{~mol} / \mathrm{l}$ in the basin water caused $10-30 \%$ metamorphosis acceleration. Lack of thyroxine due to thyroidectomy brings metamorphosis to a standstill $[16,17]$.

It was further found that hypophysectomized Rana pipiens larvae immersed in different concentrations of thyroxine at an early non-feeding stage before gill appearance only reach certain developmental stages and then remain in them. This was inferred from experiments where immersion at concentration $2.2 \times 10^{-12} \mathrm{~mol} / \mathrm{l}$ DL-thyroxine sufficed only to reach an early two-legged stage, whilst immersion at concentrations about $2.2 \mathrm{x}$ $10^{-10} \mathrm{~mol} / \mathrm{l}$ and $6.7 \times 10^{-10} \mathrm{~mol} / \mathrm{l}$ were necessary in order for larvae to reach the four-legged and juvenile stage, respectively [18].

Amphibian larvae are reported to be sensitive to thyroxine from very early stages on - even before gill reduction [19-22]. Premature tail shrinkage can be induced in early stages; this effect, however, can be achieved in two-legged tadpoles after a much shorter period of thyroxine treatment. This is the outcome of a study where larvae from non-feeding stages up to the two-legged stage reacted with tail shrinkage to $5.6 \times 10^{-8}$ $\mathrm{mol} / \mathrm{l}$ thyroxine solution at $23^{\circ} \mathrm{C}$. Tail shrinkage occurred in all tadpoles, the latent period of response was 14.2 days in animals in the larvae non-feeding stage and 4.9 days in two-legged tadpoles [22]. It is generally agreed that most larval tissues become responsive to thyroid hormones well before significant amounts of thyroid hormones are available [23]. Sensitization appears to develop successively according to type of tissue, the hind-limb buds are the last ones to respond in early tadpole development. Gill shrinkage induced by exogenous thyroxine has been reported for a urodele [21].

As a whole, thyroxine plays a more important role as active hormone in pre-metamorphic tadpoles than it is thought to play in mammals development [24]. Responses to triiodothyronine ( $\mathrm{T}_{3}$ ) can be provoked after only two to four days, i.e. earlier than $\mathrm{T}_{4}$ [20]. No literature was found on the effects of thyroxine sodium pentahydrate.

The natural plasma level of iodine / thyroxine changes during and after spontaneous metamorphosis, with slow increase during the two-legged stage, rapid increase during the four-legged stage with culmination shortly before onset of tail reduction, and then rapid decrease during tail reduction [25]. This high plasma level is interpreted as due to increased synthesis of thyroid hormone before tail reabsorption begins [26], due to higher release into the circulation and increased tissue saturation with thyroxine. Tissue would become increasingly avid for thyroxine before plasma level increases [23].

As a rule and as known from experiments with radioiodine, iodine begins to be trapped and stored already at the non-feeding stages prior to the appearance of thyroid follicles and independent of thyroid-stimulating hormone (TSH) stimulation [27,28]. Iodine uptake rises about 15-fold during the two-legged stage [28] and peaks upon transition to the four-legged stage [29,30]. This is assumed to be the period of most active synthesis and storage of thyroid hormone, before stored hormone is released to mediate climax (see above). After tadpoles entered the four-legged stage, but before tail shrinkage, iodine absorption is reduced to a small 
percentage [23]. This results from thickening of the skin, shrinkage of the gills and cessation of feeding. Experiments showed that reactions can still be induced when iodine is injected, but not when it is added to the water around animals [28,31]. However there is already accumulation of iodine in the gut during this phase [32].

When animals are treated with moderate doses of $\mathrm{NaClO}_{4}$ in order to block their thyroid gland before the twolegged stage, metamorphosis does not proceed. In a variant of this experiment performed in small scale, tadpoles were treated with $\mathrm{NaClO}_{4}$ when their hind legs were already developed, whereupon metamorphosis continued (Bufo viridis, [25]). Furthermore, tadpoles are known to be most sensitive to stress during climax, which is when most physiological transformations occur [25].

However, thyroxine not only enhances metamorphosis; when applied at concentration $1.1 \times 10^{-6} \mathrm{~mol} / \mathrm{l}$ (Lthyroxine sodium pentahydrate) in the basin water at the two-legged stage, it blocks amphibian development leading to deformation and ultimately death. This was found inadvertently in early experiments (personal communication by Scherer).

Interestingly, in the treated group body length increased to about $150 \%$ compared to the control group, and tail length decreased to about 50\%. Front limbs only occurred in the control group, but not in the thyroxine 10 6-group. All tadpoles treated with thyroxine $1.1 \times 10^{-6} \mathrm{~mol} / \mathrm{l}$ died on the sixth day of exposure, before their front limbs had appeared. At this time tadpoles in the control group had already started to enter the fourlegged stage.

No literature was found on dose-effect relationship when low concentrations of thyroxine are applied to an induced/accelerated metamorphosis state. In any case, no effects are expected at concentration $1.1 \times 10^{-15}$ $\mathrm{mol} / \mathrm{l}$. This is the detection threshold of measurements performed at our laboratory during high dilution experiments to check contamination (K. Hagmueller, Institute for Zoology, University of Graz). Pilot studies on dilutions of thyroxine prepared according to homeopathic technique $\left(1.1 \times 10^{-6}\right.$, final concentration in the

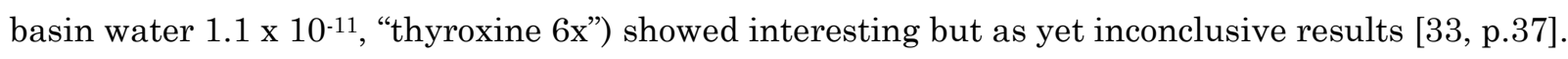

\section{Research question}

The research question is whether thyroxine at different potencies (" $8 \mathrm{x}$ " $=1.1 \times 10^{-8} \mathrm{~mol} / \mathrm{l}=$ final concentration in the basin water $1.1 \times 10^{-13} \mathrm{~mol} / \mathrm{l}$, or " $30 \mathrm{x}$ ", i.e. at concentration beyond Avogadro's limit) has any influence on metamorphosis speed in Rana temporaria and if so, whether such influence can be enhanced by pretreating (hyperstimulation) animals with thyroxine.

Between 1990 and 2010, the following types of study were performed: treatment from the two-legged stage on (with three sub-studies, i.e. "type I" lowland animals and thyroxine 8x, "type II" lowland animals and thyroxine 30x, "type III" highland animals and thyroxine 30x - each with two sub-types, i.e. inert animals and hyperstimulated animals); treatment from the spawn stage ("type IV", hyperstimulated lowland animals treated with thyroxine 30x). These experiments were inspired by the appeal of intoxication studies as an interesting tool for research in the field of homeopathy: an organism is first intoxicated with an agent at sufficiently high dose and then an attempt at detoxification or "cure" is made by applying the same agent in diluted and agitated ("potentiated") form.

Our initial choice of the amphibian model was motivated by the fact that during metamorphosis rapid increase of the thyroxine level occurs in animals that may justify the notion of an "exceptional" (albeit not intoxicated) state (studies of sub-type "inert animals"). In studies of sub-type "hyperstimulated animals", animals are artificially stimulated (i.e. "intoxicated") with thyroxine, before an attempt at "cure" is made by applying thyroxine in diluted and potentiated form. 
Rana temporaria larvae from different biotopes (lowland, i.e. 200 - $400 \mathrm{~m}$ above sea level, or highland, i.e. $1,400-1,600 \mathrm{~m}$ above sea level) were treated at different stages (spawn and two-legged) with different dilutions of thyroxine prepared according homeopathic technique ("potentiation", Table 1). Analogously potentiated water was used as control. For details on the preparation process, see below.

Table 1. Effect of diluted and agitated thyroxine on amphibian metamorphosis. Overview on studies performed. For further information, see text.

\begin{tabular}{|c|c|c|c|c|c|}
\hline $\begin{array}{c}\text { Type of } \\
\text { study }\end{array}$ & $\begin{array}{c}\text { Source of } \\
\text { animals }\end{array}$ & Onset of study & Dilution used & A - inert & B - hyperstimulated \\
\hline I & lowland & two-legged & $8 x, 24 h$ & I.I & I.II \\
\hline II & lowland & two-legged & $30 x, 24 / 48 \mathrm{~h}$ & II.I & II.II \\
\hline III & lowland & spawn & $30 x, 48 h$ & - & III \\
\hline
\end{tabular}

Development was monitored by documenting the number of animals that entered the four-legged stage. As a rule experiments were carried out by different researchers in parallel. All experiments were performed blind. Each laboratory had its own independent authority responsible for the blinding procedure. The same blinding method was used at each center. Substances were prepared in pairs. All substances were prepared in glass vials identifiable by the plaintext designation on the pull-off label. Blinding was performed within pairs. All solutions were left in the glass vials to avoid any extraneous influence through decanting. The plaintext labels were then removed by the blinding authority and replaced with labels bearing encoded designations. The code was not made known until after presentation of the results. For reasons of laboratory convenience (danger of cross-contamination due to intricate handling) we abstained from using more than one vial per substance.

For this survey, chi-square tests were performed for the measuring point when in experiments of type I.I and II.I (inert animals) about $70 \%$ and in experiments of type I.II, II.II or III (hyperstimulated animals; hyperstimulation in itself speeds up development by about $20 \%$ ) about $90 \%$ of animals had reached the fourlegged stage: frequencies (two-legged test animals / two-legged control animals / four-legged test animals / four-legged control animals) were entered in two-by-two-tables.

At that measuring point, the effect size (Cohen's d, standardized difference of means $=$ absolute difference between means of verum and control group, divided by standard deviation (SD)) was calculated. An effect size is considered small when higher than 0.2, medium when higher than 0.5 and large when higher than 0.8. Details on further evaluation are described below.

\section{Study type I, lowland animals and thyroxine $8 x$}

Study type I concerns the influence of thyroxine in moderate dilution prepared according to homeopathic technique (thyroxine 8x) on metamorphosis in lowland Rana temporaria (34). For type I.I experiments inert, i.e. non-pretreated lowland animals were used, and for type I.II experiments lowland thyroxinehyperstimulated animals were used.

\section{Laboratories and researchers}


The experiments of types I.I and I.II were carried out in parallel by 3 researchers: Waltraud SchererPongratz, Boltzmann Institute Graz, Christa Zausner-Lukitsch, Institute of Zoology, Vienna University, and Heimo Lassnig, Federal Institute of Veterinary Investigation, Graz [34]. An additional type I.I experiment was carried out by Conrad Heckmann, Tubingen University [35].

\section{Animals, staging, water and further laboratory conditions}

Rana temporaria larvae were taken from lowland pools ca. $300 \mathrm{~m}$ above sea level in Styria, Austria. The starting stage was defined as the point when the hind legs of two-legged tadpoles are straddled so that one can merely see through the triangle formed by thigh, shank, and tail (see ref 42, figure 1, left). This point of development occurs during Gosner's stage 31 [36]. Tadpoles were observed until their forelegs, which are preformed under the skin, broke through and animals had thus entered the four-legged stage (see ref 42 , figure 1, right).

At a certain point of development, the forelegs break through almost instantaneously. Thus, this parameter seems well suited for defining the final stage. Inter-rater reliability of counting was assessed in collaboration with different authorities from the Institute of Zoology of Graz University as well as from the Environmental Agency of Styria County. Some counting results were also documented photographically.

Basins contained $6 \mathrm{l}$ of water each (see ref 42, figure 2). Water samples from type I experiments were analyzed by Institute of Hygienics and Institute of Endocrinology of Graz University prior to the experiment. Pollutants such as heavy metals, chlorine or iodine were not found.

Twenty animals were allotted to each of a total of 60 white plastic basins according to a random procedure. This was performed in the same way in all centers, 20 basins were used in each laboratory. One by one, 20 animals were fished out of the main tub and distributed over the basins so that there was one in each. This was repeated 19 times. The purpose of this procedure was to ensure that animals were distributed homogenously as a function of their level of activity and swimming behavior in the main tub. The experimental design was the same at each center, involving a total of 20 basins distributed five basins for each of four different treatment groups (two inert groups for type I.I experiment and two hyperstimulated groups for type I.II, see below). Basins were arranged in five rows of four, each row contained two basins from each treatment group. The spatial arrangement of groups within rows alternated from one row to the next, i.e. basins with identical treatment groups were arranged in diagonals, and this arrangement was left unchanged all throughout the experiment to avoid the danger of cross-contamination through splashing. Indirect natural light was used, temperature was $20^{\circ} \mathrm{C}+/-1^{\circ} \mathrm{C}$. Tadpoles were fed blanched greens (lettuce) ad libitum.

\section{Preparation and administration of test solutions}

A stock solution of tetraiodothyronine sodium pentahydrate ( $\mathrm{T}_{4}$, Sigma) in $40 \%$ ethanol (vol/vol) was prepared $\left(1.1 \times 10^{-4} \mathrm{~mol} / \mathrm{l}\right)$. To prepare test dilution thyroxine $8 \mathrm{x}$, the stock solution $\left(1.1 \times 10^{-4} \mathrm{~mol} / \mathrm{l}\right)$ was further diluted with pure double distilled water in 4 1:10 steps at ambient temperature, and agitated after each dilution step according to standardized homeopathic pharmacotechnics [37]. Using disposable pipettes, $1 \mathrm{ml}$ of the precedent dilution was added to $9 \mathrm{ml}$ of water in a $20 \mathrm{ml}$ vial. The vial was banged 30 times against a rubber impediment at approximately $0.5 \mathrm{sec}$ intervals to create mechanical shocks. For preparation of control, $40 \%$ ethanol (vol/vol) was analogously further diluted with pure double distilled water in 4 1:10 steps and agitated after each dilution step (water $8 \mathrm{x}$ ). Probes prepared by the same method were checked for $\mathrm{T}_{4}$ concentration by means of chemiluminescence prior to the experiment. Final thyroxine concentration of dilution thyroxine $8 \mathrm{x}$ in the basin water was $1.1 \times 10^{-13} \mathrm{~mol} / \mathrm{l}$ after the first application.

Two groups of animals were exposed to stock solution diluted in the basin water (immersion in thyroxine $1.1 \mathrm{x}$ $10^{-8} \mathrm{~mol} / \mathrm{l}$, hyperstimulated groups). Two other groups were kept in tap water with an analogous concentration 
of ethanol. One of the hyperstimulated groups and one of the inert groups were then treated with thyroxine $8 \mathrm{x}$, and the others were treated with water $8 \mathrm{x}$.

As inferred from the preparation protocol, pretreatment (control versus hyperstimulation, groups "I" and ".II", see below) consisted in immersing the animals in thyroxine or control solution containing 4 ppbv (part per billion per volume) ethanol. After the first application of thyroxine or control solution in the actual treatment phase, all four groups were immersed in thyroxine or control solution containing 40 ppqv ethanol. It was thus ensured that any differences in metamorphosis speed within either the two pretreated or two nonpretreated groups could not be attributable to ethanol.

Three microliters of probe dilutions (thyroxine $8 \mathrm{x}$ or water $8 \mathrm{x}$ ) were added per animal and $300 \mathrm{ml}$ of basin water (i.e. 60 microliters per 6 l-basin) at 24-hour intervals.

\section{Database}

Animals were treated blindly with: a. normal water + water $8 \mathrm{x}$ (inert control group I.I), b. normal water + thyroxine $8 \mathrm{x}$ (inert test group I.I), c. thyroxine $10^{-8}+$ water $8 \mathrm{x}$ (hyperstimulated control group I.II), $d$. thyroxine $10^{-8}+$ thyroxine $8 \mathrm{x}$ (hyperstimulated test group I.II). At each center, five basins (i.e. 100 animals) were used for each of the four treatment groups. A total of 1,200 animals were involved.

No animals in the two-legged stage were lost. The few animals in the 4-legged stage that died were counted as four-legged and removed from the basin.

\section{Comparison and evaluation of data}

Comparison and evaluation of data has been described in detail in (42). Measures time-points are defined on the basis of values yielded by both thyroxine 30x and water 30x groups to avoid artificial differences in variability. The range from $0 \%$ to $100 \%$ over which the fraction of four-legged animals progresses in the course of an experiment is divided into $10 \%$-intervals and mapped on a corresponding relative time scale from 1 to 9. Each measurement is then assigned to the point (reference point) on the time scale to which it is closest (e.g. values between $46 \%$ and $54 \%$ are all assigned to reference point 5). These values are aggregated over all experiments within test- and control-group.

Main evaluation was performed by means of chi-square test at the 70\%-measuring point for the inert groups (I.I) and at the 90\%-measuring point for the hyperstimulated groups (I.II). Aggregate values obtained for treatment thyroxine $8 \mathrm{x}$ versus water $8 \mathrm{x}$ both in the inert and hyperstimulated groups were analyzed by way of logistic regression analysis. Cox's proportional hazards model was also applied. This method considers the time required to reach the four-legged stage and takes each data set with all reference points (days 1-10) into account [34]. In both tests the pooled data were assessed by determining p-values over the accumulated raw data at the basins level as well as the p-values at individual experiments level. Mean values and standard deviations were calculated.

\section{Study type II, lowland animals and thyroxine 30x}

Study type II concerns the influence of a high dilution of thyroxine "thyroxine 30x" on metamorphosis in lowland Rana temporaria [33,38, and personal communication by Scherer]. For type II.I experiments inert, i.e. non-pretreated lowland animals were used, and for type II.II lowland animals hyperstimulated with thyroxine $\left(1.1 \times 10^{-8} \mathrm{~mol} / \mathrm{l}\right)$. Temperature was $21^{\circ} \mathrm{C}+/-1^{\circ} \mathrm{C}$. Experiments were performed by one researcher (Scherer). For further details on methods, see explanations on study type I above. 
To prepare test dilution thyroxine $30 \mathrm{x}$, the stock solution $\left(1.1 \times 10^{-4} \mathrm{~mol} / \mathrm{l}\right)$ (see type I studies above) was further diluted with pure double distilled water in 26 1:10 steps and agitated after each dilution step according to a standardized protocol. Analogously, $40 \%$ ethanol (vol $/ \mathrm{vol}$ ) was further diluted with pure double distilled water in 26 steps 1:10 (water 30x). Probe dilutions were added at 24-h or 48-h intervals, i.e. application intervals were not uniform across experiments. For further details on methods, see explanations on study type I above.

\section{Study type III, hyperstimulated lowland animals treated with thyroxine 30x from the spawn stage on}

Study type III concerns the influence of thyroxine 30x compared to water 30x on hyperstimulated lowland Rana temporaria treated from the spawn stage on [44]. The objective of study type IV was to investigate whether earlier onset of pretreatment with thyroxine $\left(1.1 \times 10^{-8} \mathrm{~mol} / \mathrm{l}\right.$, prepared in pure water) sensitizes lowland animals to thyroxine 30x.

The influence of thyroxine 30x on metamorphosis was studied in lowland Rana temporaria from the spawn stage on. Hyperstimulated animals (spawn, later larvae) were treated either with thyroxine 30x or water 30x. Development was monitored by documenting the number of animals that entered the four-legged stage. Temperature was $21+/-1^{\circ} \mathrm{C}$. The experiment was performed by one researcher (Helmut Graunke, Interuniversity College). For further details on methods, see study types I and II above.

\section{Results}

\section{Study type I, lowland animals and thyroxine $8 \mathbf{x}$}

In type I.I experiments (non-hyperstimulated animals) performed by Scherer and Zausner, the number of animals that reached the four-legged stage at defined measuring points was slightly smaller in the group treated with thyroxine $8 \mathrm{x}$ compared to water $8 \mathrm{x}$. In Lassnig no difference was found between groups. Heckmann found slightly higher values in thyroxine 8x-group compared to control group [35]. Overall difference at the $70 \%$ measuring point was not statistically significant ( $p>0.05$ ). Use of other statistical methods led to similar results (for details, see [34]; 1 SD was $+/-6 \%$ in both test and control group, and effect size was 0.3 (small).

In type I.II experiments (hyperstimulated animals), the number of animals that reached the four-legged stage was smaller in hyperstimulated thyroxine 8x-group compared to hyperstimulated water 8x-group. The inhibiting effect at the $90 \%$ measuring point was statistically significant in Scherer $(\mathrm{p}<0.05)$ and Zausner $(\mathrm{p}$ $<0.01$ ) but not of Lassnig ( $p>0.05$ ) laboratory. When data were pooled effect was significant $(\mathrm{p}<0.01) ; 1$ SD was about $+/-14 \%$ in both test and control group, and effect size was 0.82 (large) (Figure 1). 


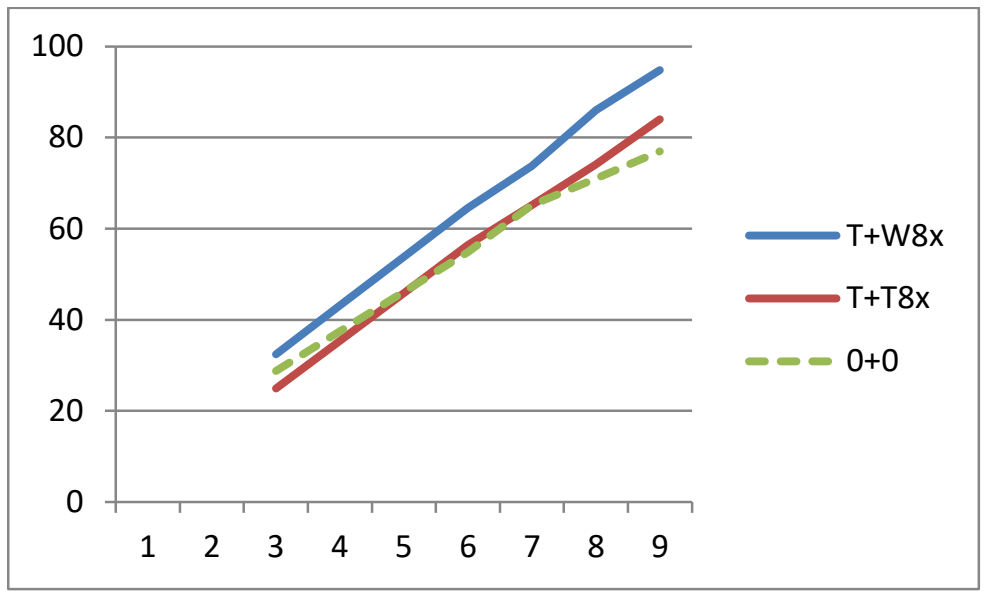

Figure 1. Influence of moderately diluted and agitated thyroxine tested versus analogously prepared water on hyperstimulated lowland amphibians. Pooled results from three researchers. Ordinate $=$ cumulative frequency of four-legged tadpoles in \% $(=\mathrm{N})$. Abscissa = points in time. Blue dotted line: frequency of animals treated with water $8 \mathrm{x}$; red dotted line: with thyroxine $8 \mathrm{x}$; Blue line: frequency of hyperstimulated animals treated with water $8 \mathrm{x}$; red line: hyperstimulated animals treated with thyroxine $8 \mathrm{x}$, green dotted line: nonhyperstimulated not treated animals. For explanation, see text. Data combined and recalculated from (39).

Table 2: Details of sub-experiments on the influence of moderately diluted and agitated thyroxine on hyperstimulated lowland amphibians. ST: "steps of ten": see Methods; black figures: raw data; blue: sums of raw data from T30x + W30x groups for calculation of "ST"; red: application of "ST" to T30x + W30x groups separately. (Table 2 is available as a supplementary xls file [58])

\section{Study type II, lowland animals and thyroxine 30x}

In types II.I and II.II experiments there was no statistically significant difference between test and control groups $(p>0.05)$.

\section{Study type III, hyperstimulated lowland animals treated with thyroxine 30x from the spawn stage on}

Animals treated with test solution were found to metamorphosize slower than control animals, i.e. effect of thyroxine 30x was (as in the previous studies) opposed to thyroxine usual effect. The number of test animals that reached the four-legged stage at defined time-points was smaller in the group treated with thyroxine 30x at some but not at all time-points compared to water 30x (Figure 2). At the 90\%-measuring point, this difference was significant $(p<0.01)$. 


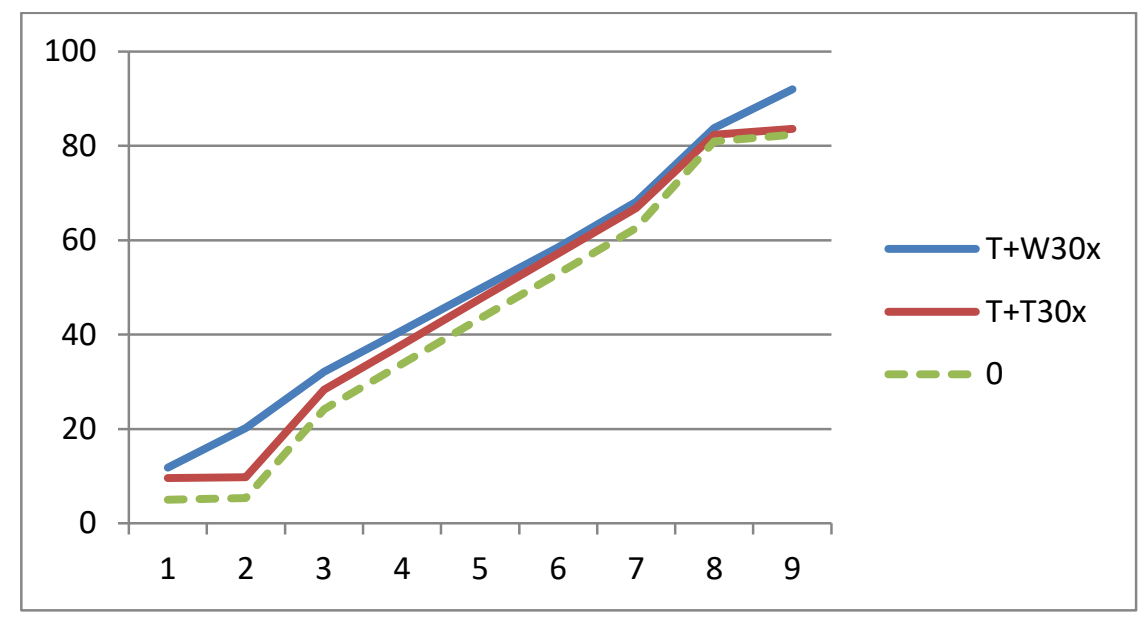

Figure 2. Influence of extremely diluted and agitated thyroxine added from the spawn stage onwards on hyperstimulated lowland amphibians. $\mathrm{N}=500$ per group. Green dotted line: non-hyperstimulated animals treated with inert water. For further explanation, see legend to Figure 1 and text. Data recalculated from (44).

Table 3. Details on the experiment on the influence of extremely diluted and agitated thyroxine added from the spawn stage onward on hyperstimulated lowland amphibians. For explanation, see table 2. (Table 3 is available as a supplementary xls file [59])

\section{Discussion}

These experiments were inspired by the appeal of intoxication studies as an interesting tool for research in the field of homeopathy: an organism is first intoxicated with a molecular agent and then an attempt at detoxification or "cure" is made by applying the same agent in diluted and agitated ("potentiated") form. Initial choice of the amphibian model was motivated by the fact that rapid increase in thyroxine blood levels occurs during metamorphosis. We believe this justifies the notion of an "exceptional" (albeit non-intoxicated) state (type “.I" studies). In type ".II" studies, animals are artificially hyperstimulated by thyroxine (i.e. "intoxicated") before an attempt at "cure" is made by applying thyroxine in potentiated form.

Inert lowland amphibians were found not to visibly react to thyroxine $8 \mathrm{x}$, but thyroxine $8 \mathrm{x}$ can slow down metamorphosis in lowland amphibians when pretreated (hyperstimulated) with thyroxine. In other words, pretreatment with thyroxine can enhance thyroxine 8x reverse or "curative" effect. Furthermore, amphibians from lowland biotopes were found not to visibly react to high dilution thyroxine 30x.

In contrast, thyroxine 30x does slow down metamorphosis in inert highland amphibians [42]. This was observed by five researchers in most of altogether 20 experiments, and it seems to be the most reliable bioassay found in research in amphibians and diluted agitated thyroxine so far. However, pretreatment (hyperstimulation) of highland animals with thyroxine does not lead to a more marked effect of thyroxine 30x; rather the effect was smaller compared to non.pretreatment [42].

In a pilot study thyroxine 30x was found to slow down metamorphosis in lowland amphibians hyperstimulated with thyroxine from the spawn stage on. In other words, pretreatment with thyroxine can enhance a reverse or "curative" effect of thyroxine 30x. However, the special design tested has to be further 
investigated before general conclusions on the possibility to influence lowland Rana temporaria by extremely diluted thyroxine can be drawn.

Different degrees of the experimental effect seem to be due to different degrees of amphibian sensitivity towards diluted and agitated thyroxine. This in turn seems to depend on whether animals come from lowland or highland biotopes.

From these studies we conclude that there appears to be a relationship between the effect of thyroxine prepared according to homeopathic technique and naturally or artificially elevated thyroxine levels in animals during metamorphosis. It is reasonable to suppose that highland larvae of Rana temporaria become adapted to an environment requiring comparatively higher thyroxine levels or high sensitivity to thyroxine. This would be a plausible explanation for the consistent response found in experiments performed with extremely diluted thyroxine.

These results suggest that administering diluted and agitated thyroxine to amphibian larvae during thyroxine-controlled metamorphosis is in a certain sense analogous to the intoxication-detoxification concept used in other homeopathy research models, although in our experimental model the intoxication dose and its effect on responsiveness do not seem to correlate in a linear manner.

Results of independent researchers backing some of our findings $[45,46,47]$ were described in $(42$, see discussion section). Guedes et al. investigated histological changes during tail absorption and found higher apoptosis rate (programmed cell death) in the test group [46]. Interesting work has already been performed regarding signal proteins modulation by dilutions prepared according to homeopathic technique [12,48]. However, in keeping with our principle of avoiding invasive methods we chose not to pursue this question any further.

It is interesting to note that a thyroxine-sensitive state may be influenced by diluted and agitated thyroxine, and that even after extreme dilution beyond Avogadro's limit, information from the original thyroxine molecule appears to be stored in or linked to liquid water. Some biophysical theories support the possibility of such findings [49]. Physics research revealed through radiation coupling that water dipoles might develop phase coherent oscillations [50]. It was suggested that these can be modulated as a time-ordered pattern of signals forming "liquid crystals". UV spectroscopy may be an adequate tool for research in this field [51]. We are inclined to believe that the theoretical explanation of homeopathy - just as the explanation of a wide range of other phenomena in physiology, psychology and epistemology - will be inspired in the future by de Broglie's concept of the wave nature of particles and the particle nature of waves $[52,53]$.

Research along biophysics line may be stimulated by the finding that diluted and agitated substances sealed in glass vials may influence physiological processes [54]. Using two-legged Rana temporaria, researchers found in some but not all cases that animals treated with thyroxine 30x sealed in glass vials metamorphosed slower than control animals treated with water 30x sealed in glass vials (figure 3 ).

A total of seven sets of experiments were performed. The number of animals that reached the four-legged stage was smaller in the test compared to the control group. An inhibiting effect at the $70 \%$ measuring point was statistically significant when all data were pooled $(p<0.01)$; for the experiments treated separately, it was significant only in Scherer-Pongratz laboratory $(p<0.01)$, while it was visible as a trend $(p>0.05)$ in Endler, Vinattieri (Turin) and Hilgers (Vienna) laboratories, and there was no difference between groups ( $p>$ 0.05) in Dieterle main experiment (Graz). However, when in a small experiment Dieterle used quartz glass vials instead of soft soda glass, there was less metamorphosis speed in thyroxine 30x compared to control group (figure 4). 


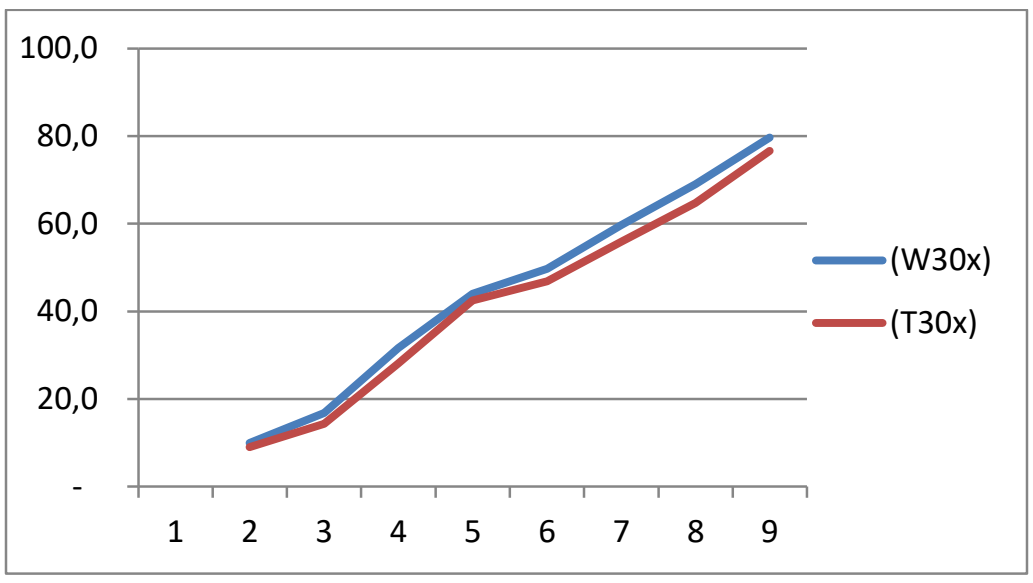

Figure 3. Influence of extremely diluted and agitated thyroxine sealed in glass vials. $\mathrm{N}=1710$ per group. For further explanation, see legend to Figure 1 and text. Data recalculated from (55).

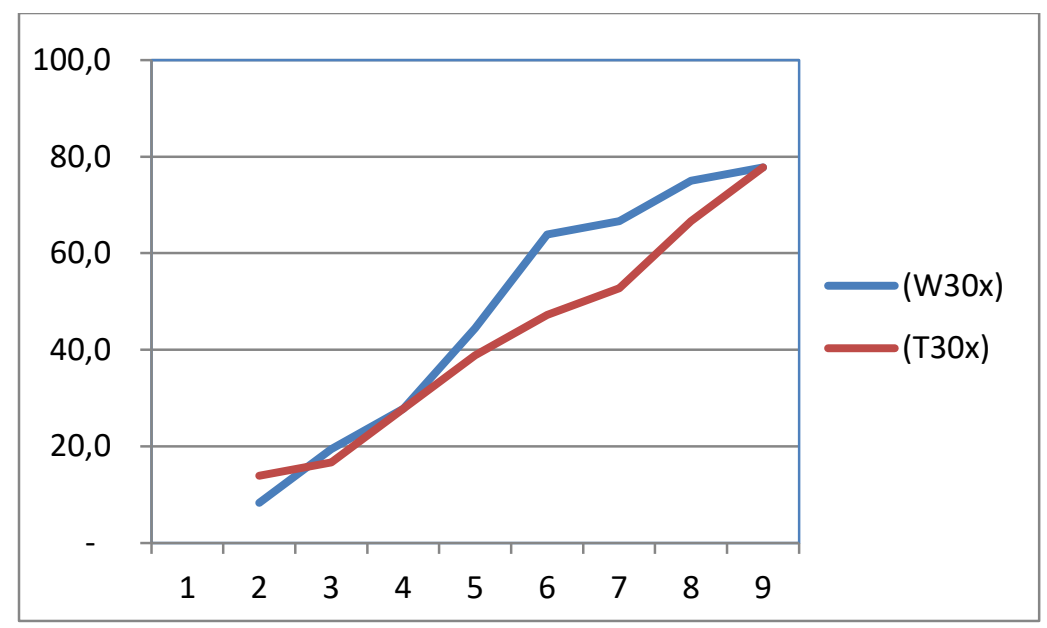

Figure 4. Result of a pilot experiment using thyroxine 30x sealed in quartz glass vials. $\mathrm{N}=36$ per group. For further explanation, see legend to figure 1 and text. Data recalculated from (55).

A comprehensive overview on the state of repetitions of fundamental research models for dilutions beyond $10^{23}$ was given in ref 10 . Research into homeopathy was described in the divulgation-book "Homeopathy - An Expedition Report” [33]. This book also discusses further types of studies with amphibians [56,57].

\section{Acknowledgements}

Thanks are due to all who performed experiments between 1990 and 2010. The paper presented here is part of a doctoral dissertation. 


\section{References}

[1] Baumgartner S. Reproductions and reproducibility in homeopathy: Dogma or Tool? J Altern Complement Med 2005; 11: 771-772

[2] Baumgartner S. The state of basic research on homeopathy. In: New directions in homeopathy research Advice from an interdisciplinary conference. Eds: H Albrecht, C Witt, KVC-Verlag, Essen, Germany, 107-130 (2009)

[3] Albrecht H, van Wijk R, Dittloff S. A new database on basic research in homeopathy. Homeopathy 2002; 91: 162-165.

[4] Endler PC. Fundamental research into high dilution effects. A classification of non-clinical research topics. In: Fundamental Research in Ultra High Dilution and Homoeopathy. Eds: J Schulte, P C Endler, Kluwer Academic Publishers, Dordrecht (Netherlands) 1998.

[5] Göldner C. [Review and evaluation of new toxicological experiments performed with homeopathic preparations.] Review und Evaluierung von neuen, mit homöopathischen Zubereitungen durchgeführten toxikologischen Experimenten. [Dissertation] University of Graz 2006.

[6] Linde K, Jonas WB, Melchart D, Worku F, Wagner H and Eitel F. Critical review and meta-analysis of serial agitated dilutions in experimental toxicology. Hum Exp Toxicol 1994; 13: 481-482.

[7] Vickers AJ. Independent replication of pre-clinical research in homoeopathy: a systematic review. Res Compl Med / Forsch Komplementaermed 1999; 6: 311-320.

[8] Walach H, Jones WB, Ives J, Wijk RV, Weingartner O. Research on homeopathy: state of the art. J Altern Complement Med 2005; 11: 813-29.

[9] Witt CM, Bluth M, Albrecht H, Weisshuhn TE, Baumgartner S, Willich SN: The in vitro evidence for an effect of high homeopathic potencies - a system review of the literature. Complement Ther Med 2007; 15: 12838.

[10] Endler PC, Thieves K, Reich R, Matthiessen PF, Bonamin L, Scherr C, Baumgartner S. Repetitions of fundamental research models for homeopathically prepared dilutions beyond 10e-23: a bibliometric study. Homeopathy 2010; 99: 25-36.

[11] Jäger T, Scherr C, Simon M, Heusser P, Baumgartner S. Effects of Homeopathic Arsenicum Album, Nosode and Gibberellic Acid Preparations on the Growth Rate of Arsenic-Impaired Duckweed (Lemna gibba L.). The Scientific World Journal 2010; 10: 2112 - 2129.

[12] Endler PC, Matzer W, Reich C, Reischl T, Hartmann AM, Thieves K, Pfleger A, Hofäcker J, Lothaller H, Scherer-Pongratz W. Seasonal variation of the effect of extremely diluted agitated gibberellic acid (10e-30) on wheat stalk growth - a multi researcher study. The Scientific World Journal 2011; 11: 1667-1678.

[13] Roth C. Literature review and critical analysis on the topic of "In- and Detoxication Experiments in Homeopathy”. Berlin Res J Hom 1991; 1: 111-117.

[14] König K. [On the effect of extremely attenuated ("homeopathic") dilutions of metallic salts on the development and growth of tadpoles]. Über die Wirkung extrem verdünnter ("homöopathischer") Metallsalzlösungen auf Entwicklung und Wachstum von Kaulquappen. Zschft ges exp Med 1927; 56: 881-893.

[15] Giersberg H. [Hormones] Hormone. Eds: Springer, Berlin (Germany) 1972. 
[16] Wehner R, Gehring G. [Zoology] Zoologie. Eds: Thieme, Stuttgart (Germany) 1990.

[17] Pitt-Rivers R, Trotter WR. The Thyroid Gland. Eds: Butterworth, London (UK) 1964.

[18] Kollros JJ. Mechanisms of amphibian metamorphosis: Hormones. Amer Zool 1961; 8: 107-114.

[19] Moser H. [A contribution to the analysis of thyroxine effects in studies with tadpoles and on the question about the conclusion of the early dispositions of the metamorphosis reaction system] Ein Beitrag zur Analyse der Thyroxinwirkung im Kaulquappenversuch und zur Frage des Zustandekommens der Fruehbereitschaft des Metamorphose-Reaktionssystems. Rev Suisse Zool 1950; 57:1-144.

[20] Tata JR. Early metamorphic competence of Xenopus larvae. Develop Biol 1968; 18: 415-441.

[21] Prahlad KV, DeLanney LE. A study of induced metamorphosis in the Axolotl. J Exp Zool 1965; 160:137146.

[22] Chou HI, Kollros JJ. Stage modified responses to thyroid hormones in Anurans. Gen Comp Ednocrinol 1974; 22: 255-260.

[23] Dodd MHJ, Dodd JM. The Biology of Metamorphosis. In: Physiology of Amphibia, vol. 3. Eds: Academic Press, London (UK) 467-599; 1976.

[24] Galton VA, Cohen JKS. Action of thyroid hormones in premetamorphic tadpoles: an important role for thyroxine? Endocrinology 1980; 107:1820-1826.

[25] Weil MR. Changes in plasma thyroxine levels during and after spontaneous metamorphosis in a natural population of the green frog, Rana clamitans. Gen Comp Endocrinol 1986; 62: 8-12.

[26] Zelzer G. [In vitro researches into intestinal phenylalanine reabsorption before and during metamorphosis in Bufo viridis tadpoles] In vitro Untersuchungen zur intestinalen Phenylalaninresorpion vor und waehrend der Metamorphose bei Kaulquappen von Bufo viridis. Doctoral dissertation, Graz University. 1990.

[27] Saxen L. The onset of thyroid activity in relation to the cytodifferentiation of the anterior pituitary. Acta Anat 1958; 32: 87-100.

[28] Kaye NW. Interrelationships of the thyroid and the pituitary in embryonic and premetamorphic stages of the frog Rana pipiens. Gen Comp Endocrinol 1961; 1: 1-19.

[29] Dodd JM. Studies on amphibian metamorphosis using I131. J Physiolog (London) 1955; 130: 11.

[30] Hanaoka Y. Uptake of $\mathrm{I}^{131}$ by the thyroid gland during metamorphosis in Xenopus laevis. J Fac Sci Hokkaido Univ 1966; 16: 106-112.

[31] Neuenschwander P. [Thyroid ultrastructure and iodine intake in African clawed frog (Xenopus laevis daud.) larvae] Ultrastruktur und Jodaufnahme der Schilddruese bei Larven des Krallenfrosches (Xenopus laevis daud.) Z Zellforsch Mikrosk Anat 1972; 130: 553-574.

[32] Lipner H, Hazen S. Extra thyroidal iodine pump in tadpoles (Rana grylio). Science 1962; 138: 898-899.

[33] Endler PC. Homeopathy research - an expedition report. An old healing system gains plausibility. Eds: edition@inter-uni.net, Graz (Austria) 2003. 
[34] Endler PC, Luedtke R, Heckmann C, Zausner C, Lassnig H, Scherer-Pongratz W, Haidvogl M, Frass M. Pretreatment with thyroxine (10e-8 parts by weight) enhances a "curative" effect of homeopathically prepared thyroxine (10e-13) on lowland frogs. Res Compl Med / Forsch Komplementaermed 2003; 10: 137-142.

[35] Heckmann C. [Influence of homeopathically and non-homeopathically prepared dilutions of thyroxine on the metamorphosis speed of common frog (Rana temporaria L.)] Einfluss homoeopathisch und nicht homoeopathisch hergestellter Thyroxinloesungen auf die Metamorphosegeschwindigkeit beim Grasfrosch (Rana temporaria L.). Doctoral dissertation Xenopus laevis, Tubingen University. 1997.

[36] Gosner KL. A simplified table for staging anuran embryos and larvae with notes on identification. Herpetologica 1960; 16:183-190.

[37] [Homeopathic Pharmacopoea, 1 ${ }^{\text {st }}$ edition]. Deutscher Apothekerverlag, Eds: Stuttgart and Govi Verlag, Frankfurt (Germany) 1978.

[38] Endler PC, Pongratz W, van Wijk R, Kastberger G, Haidvogl M. Effects of highly diluted succussed thyroxine on metamorphosis of highland frogs. Berlin J Research Hom 1991; 1: 151-160.

[39] Zausner C, Lassnig H, Endler PC, Scherer W, Haidvogl M, Frass M, Kastberger G, Lüdtke R. [The effect of "homeopathically" prepared thyroxine on the metamorphosis of highland amphibians. Results of a multicentric control study. Die Wirkung von "homöopathisch" zubereitetem Thyroxin auf die Metamorphose von Hochlandamphibien. Ergebnisse einer multizentrischen Kontrollstudie. Perfusion 2002; 17: 268-276.

[40] Endler PC, Schulte J. (eds.). Ultra High Dilution: Physiology and Physics. Kluwer Academic Publishers, Dordrecht (Netherlands) 1994.

[41] Schulte J, Endler PC (eds.). Fundamental Research in Ultra High Dilution and Homoeopathy. Kluwer Academic Publishers, Dordrecht (Netherlands), 1998.

[42] Lingg G, Endler PC. Highland amphibians - Recalculation of data from 1990 to 2010 on the effects of extremely diluted thyroxine. Int J High Dilution Res [online]. 2011 [cited YYYY Month dd]; 10(37): <\#from\#to.> Available from: http://www.feg.unesp.br/ ojs/index.php/ijhdr/article/view/429/541

[43] Welles SU, Endler PC, Scherer-Pongratz W, Suanjak-Traidl E, Weber S, Frass M, Spranger H, Lothaller H. Pretreatment with thyroxine (10e-8) and the effect of homeopathically prepared thyroxine $\left(10 \mathrm{e}^{-30}\right)$ on highland frogs - a multi-researcher study. Res Compl Med / Forsch Komplementaermed 2007; 14: 353-357.

[44] Graunke H, Endler PC, Scherer-Pongratz W, Frass M, Lothaller H. Treatment of lowland frogs from the spawn stage on with homeopathically prepared thyroxine (10e-30). The Scientific World Journal 2007; 7 : 1697-1702.

[45] Guedes JRP, Ferreira CM, Guimaraes HMB, Saldiva PHN, Capelozzi VL. Homeopathically prepared dilution of Rana catesbeiana thyroid glands modifies its rate of metamorphosis. Homeopathy 2004; 93:132137.

[46] Guedes JRP. [Homeopathic ultradilution of triiodothyronine alters apoptosis in Rana catesbeiana tadpoles tails: in vitro]. Ultradiluicao homeopatica de triiodotironina altera a apoptose cellular da cauda de girinos de Rana catesbeiana: in vitro. [dissertation] Sao Paulo University. 2009.

[47] ] Interuniversity College. [Pilot trial aimed at an independent replication of a study on the possibility of influencing the speed of metamorphosis of amphibian larvae by means of homeopathically diluted thyroxin (10e-30) by G. Bach, Cooperative Office for Complementary Medicine of Bern University. Report to the 
Government of the State of Styria.] Pilotversuch zur unabhängigen Wiederholung einer Studie zur Beeinflussung der Metamorphosegeschwindigkeit von Amphibienlarven durch homöopathisch verdünntes Thyroxin (10e-30) durch G. Bach, Kollegiale Instanz für Komplementärmedizin der Universität Bern. Bericht an das Amt der Steiermärkischen Landesregierung, Graz 2011.

[48] Khuda-Bukhsh AR, Bhattacharyya SS, Paul S, Dutta S, Boujedaini N, Belon P. Modulation of signal proteins: a plausible mechanism to explain how a potentized drug Secale Cor 30c diluted beyond Avogadro's Limit combats skin papilloma in mice. Evid Based Complement Alternat Med 2009; 2011.

[49] Enserink M. Newsmaker Interview: Luc Montagnier Science 2010; 330:1732.

[50] del Giudice E, Preparata G. Coherent electrodynamics in water. Eds: Schulte J, Endler PC. 89-104. 1998.

[51] Marschollek B, Nelle M, Wolf M, Baumgartner S, Heusser P, Wolf U. Effects of Exposure to Physical Factors on Homeopathic Preparations as Determined by Ultraviolet Light Spectroscopy. The Scientific World Journal 2010; 10: $49-61$.

[52] Kavarainen A. Mesoscopic theory of matter and interaction with light. Principles of self organisation in ice, water and biosystems. Eds: F N Turku, Turun Yliopiston Offsetpaino, Turku, Finland. 1992.

[53] Schulte J. Bio-Information between quantum and continuum physics. Eds: Schulte J, Endler PC. 45-68. 1998.

[54] van Wijk R, Wiegant FAC. Homeopathic remedies and pressure-induced changes in the galvanic resistance of the skin. Alkmaar: VSM. 1988.

[55] Endler PC, Heckmann C, Lauppert E, Pongratz W, Alex J, Dieterle D, Lukitsch C, Vinattieri C, Smith CW, Senekowitsch F, Moeller H, Schulte J. The metamorphosis of amphibians and information of thyroxine. In Schulte J, Endler PC (eds.). Fundamental Research in Ultra High Dilution and Homoeopathy. Kluwer Academic Publishers, Dordrecht (Netherlands), 1998.

[56] Endler PC, Pongratz W, Kastberger G, Wiegant FAC, Schulte J. The effect of highly diluted agitated thyroxine on the climbing activity of frogs. J. Vet. Hum. Tox. 1994; 36: 56-59.

[57] Endler PC, Pongratz W, Smith CW, Schulte J: Non-molecular information transfer from thyroxine to frogs in respect to 'homoeopathic' toxicology. Vet Hum Tox 1995; 37: 259-260.

[58] Kiefer P, Lingg G, Endler PC. Lowland amphibians - recalculation of data on effects of diluted thyroxine [supplementary material]. Int J High Dilution Res [online]. 2012 [cited YYYY Month DD]; 11(38):03-18. Available from: http://www.feg.unesp.br/ ojs/index.php/ijhdr/article/view/526/544

[59] Kiefer P, Lingg G, Endler PC. Lowland amphibians - recalculation of data on effects of diluted thyroxine [supplementary material]. Int J High Dilution Res [online]. 2012 [cited YYYY Month DD]; 11(38):03-18. Available from: http://www.feg.unesp.br/ ojs/index.php/ijhdr/article/view/526/545

\section{Anfíbios de terras baixas - recálculo dos dados sobre os efeitos de tiroxina diluída}

RESUMO 
Nosso artículo anterior descreve problemas metodológicos e um método geralmente aceitável de agrupamento em experimentos sobre metamorfose e a aplicação deste método aos resultados de experimentos multicêntricos realizados no curso de duas décadas $(1990$ - 2010) em anfíbios de terras altas (Rana temporaria) tratados com uma alta diluição de tiroxina preparada homeopaticamente ("30x"). As diferenças calculadas entre os grupos de tratamento concordam com as obtidas através de outros métodos de agrupamento: Tiroxina 30x de fato faz mais lenta a metamorfose nos anfíbios de terras altas. Este artigo posterior oferece um panorama mais amplo sobre a fisiologia da metamorfose e descreve a aplicação do método de agrupamento a experimentos com Rana temporaria de biótopos de terras baixas com diluição moderada ("8x") e 30x de tiroxina. Foi utilizado como controle água preparada analogamente (água 8x e 30x). Novamente, o desenvolvimento foi monitorado documentando o número de animais que entraram no estágio de 4 patas. Os experimentos foram realizados entre 1990 e 2000 por diversos pesquisadores independentemente e em cego. Como é sabido, a metamorfose pode ser acelerada por tiroxina $10^{-8} \mathrm{~mol} / \mathrm{l}$; de maneira interessante, tiroxina $8 \mathrm{x}$ pode produzir o efeito inverso, ou seja, inibidor $(\mathrm{p}<0.01)$. Contrariamente ao efeito inibidor de tiroxina 30x nas larvas de terras altas (vide acima), as larvas de 2 patas de terras baixas não responderam a tiroxina 30x ( $>0.05$ ). No entanto, foi achado um efeito inibidor sobre as larvas de terras baixas quando os animais foram tratados a partir da desova $(\mathrm{p}<0.01)$.

Palavras-chave: homeopatia, diluição, bioensaio, tiroxina, anfíbios

\section{Anfibios de tierras bajas - re-cálculo de datos sobre los efectos de tiroxina diluida}

\section{RESUMEN}

Nuestro artículo anterior describe problemas metodológicos y un método aceptable en general de agrupamiento en experimentos sobre metamorfosis y la aplicación de este método a los resultados de experimentos multicéntricos realizados durante dos décadas $(1990$ - 2010) en anfibios de tierras altas (Rana temporaria) tratados con una alta dilución de tiroxina preparada homeopáticamente ("30x"). Las diferencias calculadas entre los grupos de tratamiento están de acuerdo con las obtenidas mediante otros métodos de agrupamiento: Tiroxina 30x fehacientemente enlentece la metamorfosis en anfibios de tierras altas. Este artículo posterior ofrece un panorama más amplio de la fisiología de la metamorfosis y describe la aplicación del método de agrupamiento en experimentos con Rana temporaria de biótopos de tierras bajas con dilución moderada ("8x") y 30x de tiroxina. Se utilizó como control agua preparada análogamente (agua 8x y 30x). Nuevamente, el desarrollo fue monitoreado documentando el número de animales que entraron en el estadio de 4 patas. Os experimentos fueron realizados entre 1990 e 2000 por diversos investigadores independientemente y en ciego. Como se sabe, la metamorfosis puede ser acelerada por tiroxina $10^{-8} \mathrm{~mol} / \mathrm{l}$; de modo interesante, tiroxina $8 \mathrm{x}$ puede producir el efecto inverso, o sea, inhibidor $(\mathrm{p}<0.01)$. Contrariamente al efecto inhibidor de tiroxina 30x en larvas de tierras altas (ver antes), las larvas de 2 patas de tierras bajas no respondieron a tiroxina 30x $(\mathrm{p}>0.05)$. Sin embargo, se encontró efecto inhibidor en larvas de tierras bajas cuando los animales fueron tratados desde la freza $(\mathrm{p}<0.01)$.

Palabras-clave: homeopatía, dilución, bioensayo, tiroxina, anfibios

\section{(c)) BY-NC-ND Licensed to GIRI}

Support: authors declare that this study received no funding

Conflict of interest: authors declare there is no conflict of interest

Received: 25 October 2011; Revised: 25 February 2011; Published: 31 March 2012.

Correspondence author: Gerhard Lingg, Interuniversity College, Petrifelderstr. 4, 8042 Graz, Austria, e-mail: college@inter-uni.net

How to cite this article: Kiefer P, Lingg G, Endler PC. Lowland amphibians - recalculation of data on effects of diluted thyroxine. Int J High Dilution Res [online]. 2012 [cited YYYY Month dd]; 11(38):3-18. Available from: http://www.feg.unesp.br/ ojs/index.php/ijhdr/article/view/526/546 